\title{
INDEX TO EVALUATE CLOSED LANDFILLS BASED ON LEACHATE PARAMETERS
}

\author{
Claudio Fernando Mahler ${ }^{1, \star}$, Julia Righi de Almeida ${ }^{2}$ and João Paulo Bassin ${ }^{1}$ \\ ${ }^{1}$ COPPE/ UFRJ, Federal University of Rio de Janeiro, COPPE/Civil Engineering Program, Rio de Janeiro/RJ, Brazil \\ ${ }^{2}$ Federal University of Juiz de Fora, Department of Civil Engineering, Juiz de Fora, Brazil
}

Article Info:
Received:
6 June 2019
Revised:
5 March 2020
Accepted:
17 March 2020
Available online:
30 June 2020
Keywords:
Closed landfill
Leachate
Polluting potential
Deactivated landfill assessment
index (DLAl)

Article Info:

Revised:

17 March 2020

Available online:

June 2020

Keywords:

Leachate

Deactivated landfill assessment

index (DLAI)

\begin{abstract}
After the end of their useful life, waste landfills and their surroundings should continue to be monitored constantly. The main concern is the pollution of groundwater and surface water by leachate, which represents a serious risk to public health. In this work an index is proposed to assess the conditions of a landfill after closure. Insufficient data on the waste entering these areas causes uncertainty as to how long the material will continue to degrade. The presence of polluting elements in landfill leachate was evaluated by characterizing the effluent over a period of ten years. The leachate data were analyzed statistically to test the significance of Pearson's linear correlation coefficient. Multivariate statistical analysis was used to describe the similarity between the samples considering the total set of variables and their correlations. These results showed the importance given to certain parameters that are not relevant for Brazilian landfills, in which the presence of organic matter is high. The present work contributes by generating information for a better understanding of the impacts caused by landfills in Brazil and in most countries of the Third World, in which organic waste represents at least $50 \%$ of the waste discarded in landfills. Through the proposed Deactivated Landfill Assessment Index (DLAI), involving four-parameter analysis ( $\mathrm{pH}, \mathrm{BOD}, \mathrm{COD}$ and ammoniacal nitrogen), possible pollution threats can be detected, allowing prioritizing areas for remediation and better allocation of resources.
\end{abstract}

\section{INTRODUCTION}

Upon completion of their useful life, landfills and their surroundings should continue to be monitored. The main concern is contamination of water from transport of the leachate generated. This effluent contains hundreds of chemical products, and its management is recognized as one of the major problems associated with the operation of landfills, especially after their closure. Areas that were previously used for waste disposal often become sites of low-income settlements. Since these old landfills can continue to produce effluents and contaminate the environment for many years, it is important that they not simply be abandoned. Closed landfills should instead be monitored to prevent their irregular occupation (Schueler and Mahler, 2008). More than $50 \%$ of the waste contained in landfills in Brazil is organic matter. The lack of public policies to prioritize and invest in composting, to prevent disposal of this waste in landfills, generates very high costs, mainly for the treatment of leachate. The concentrations of ammoniacal nitrogen, for example, tend to increase after the decommissioning of the landfill, increasing the treatment costs of the effluent generated. Leachate from closed landfills may has equal or greater potential for contamination compared to that from active landfills, so post-closure remediation and monitoring actions should be continued until the leachate stabilizes and no longer poses a threat to the environment and health (Kumar and Alappat, 2005). The Leachate Pollution Index (LPI), originally proposed by Kumar and Alappat (2003) and later also applied in Kumar and Alappat (2005), Sharma et al. (2008), Rafizul et al. (2011), Bhalla et al. (2014), Krishnamurthy et al. (2015), Naveen et al. (2016) and Lothe and Sinha (2016), among others, was developed to enable comparing the pollution potential of leachate from different landfills. LPI is a single number ranging from 5 to 100 . It represents the level of leachate contamination potential of a determined landfill. It is obtained from several leachate pollution parameters at a given moment.

However, the weights attributed to each of the leachate components do not seem to be the most suitable for application in Brazilian landfills, mainly because they do not take into account the importance of organic matter, the main fraction found in the wastes. Given the high number of dumps in Brazil and the lack of resources for the manage- 
ment of municipal solid waste, the number of parameters to be analyzed in the leachate could be reduced (compared to that proposed in the LPI), at least in the control analyses. The concentrations of most heavy metals, phenols and cyanides, for example, as shown by experience in Brazilian landfills, tend to fall drastically over time, as the $\mathrm{pH}$ increases and natural processes occur in this environment (Peixoto, 2007; Teixeira et al., 2007; Galvez et al., 2008; Queiroz et al., 2011). In this case, not all of the above parameters need to be analyzed. In this article, the main results obtained by monitoring a landfill for a period of 10 years are presented to support the method proposed, the Deactivated Landfill Assessment Index (DLAl).

The aim of this study was to investigate what parameters are really important to evaluate the contamination potential of the effluent and to propose an index that could help efforts in developing countries regarding the monitoring of closed areas and support decisions regarding the allocation of resources for remediation in the post-closure phase.

\section{MATERIALS AND METHODS}

\subsection{Materials}

\subsubsection{Studied area}

The Sky Hill dumpsite is located in an area of approximately $180,000 \mathrm{~m}^{2}$ in the Caramujo district of the municipality of Niterói, state of Rio de Janeiro, Brazil. Niterói has an estimated population of 497,883 (IBGE, 2016) and produces about 700 metric tons of waste per day.

The landfill was operated for 30 years (1983-2013), generally as a dump. As of 2005 , on-site improvement works were implemented, which allowed it to be considered a controlled landfill as of 2008. This fact improved its aesthetic appearance and operating conditions, and over time its liquid and gaseous emanations declined.

\subsubsection{Monitoring of leachate, surface water and groundwa- ter}

The monitoring began in 2004 and was done during 10 years. Sixty-four effluent and water samples were collect$\mathrm{ed}$, and in relation to the leachate, a series of parameters were analyzed in duplicate: $\mathrm{pH}, \mathrm{BOD}, \mathrm{COD}$, phenols, cyanides, heavy metals and ammoniacal nitrogen. In addition to the leachate, wherein the concentration of its pollutants were compared within the effluent discharge standards set forth in CONAMA Resolution 430/2011, samples of surface and groundwater from areas surrounding the landfill were also analyzed, with the results being compared to the limits of CONAMA Resolution 420/2009, CONAMA Resolution 357/2005 and Edict 2914/2011 from the Ministry of Health, which establish standards of water quality of aquifers, water sources in general and water for human consumption and potability, respectively. Groundwater collections were carried out through a monitoring well in the landfill itself and the surrounding surface water samples were collected downstream of the disposal area. The collection of groundwater in the monitoring well was carried out with the aid of a plastic collection tube, which had a collection sealing system and tips for overflow. They were stored in specific bottles made available by the laboratory responsible for the analysis and routed under specific temperature conditions required by the lab. For surface water, $500 \mathrm{~mL}$ samples were collected in all campaigns on the river banks (river and Floralia points), at a depth of up to $30 \mathrm{~cm}$. After collection, the samples were placed in a Styrofoam box and transported to the laboratory following the standards of ABNT NBR 9897 and NBR 9898. The same procedure was used to transport the slurry samples, collected at all sites, from inside of a collection box inside the landfill. For the collection of these samples (using $500 \mathrm{~mL}$ vials), special care was required (use of masks and gloves), due to the toxicity of the liquid. The collection points are identified in Figure 1 and the methods used in the analyzes, carried out in certified laboratories, are summarized in Table 1 . The results of the analyses presented in this article were extracted from the technical reports of the project coordinated by Mahler from 2004 to 2013.

In addition to the leachate, samples of surface and groundwater from areas close to the landfill were analyzed, which showed values above the limits of CONAMA, which changed with time as the landfill started to be controlled.

\subsection{Methods}

\subsubsection{Statistical analysis}

The Statistica 7 program was used for statistical analysis of the results obtained from the landfill monitoring. Initially, descriptive statistics were used to summarize the data for all the compounds analyzed directly: mean, minimum and maximum values, standard deviation, etc. In order to verify the influence of chemical elements (effects of antagonism and synergism), the leachate data were treated and analyzed statistically to test the significance of Pearson's linear correlation coefficient. Multivariate statistical analysis (main components and clusters) was used both to describe the similarity between the samples considering the total set of variables and their correlations, and to find sets of variables that could be considered redundant. Principal component analysis (PCA) enabled transformation of the data into two dimensions, designed to transform the original variables into new uncorrelated variables. Hierarchical cluster analysis (HCA) was used to recognize patterns (similarities) of samples from a set of data obtained, presented in dendrograms. The results obtained from the statistical analysis performed with the leachate monitoring data from the Sky Hill dumpsite supported the choice of the parameters used to calculate the proposed index.

\section{RESULTS AND ANALYSES}

\subsection{Parameters analyzed in the leachate and waters surrounding the Sky Hill Dumpsite}

\subsection{1 $\mathrm{pH}, B O D$ and $C O D$}

At the start of a landfill, an acidic phase is expected with $\mathrm{pH}$ values below 7, followed by gradual elevation towards the methanogenic phase, with $\mathrm{pH}$ values above 7 (Pohland and Harper, 1985). In the Sky Hill dumpsite, the mean value observed for the entire monitoring period was 7.85 , and in the last sample collected, with the landfill deactivated four 


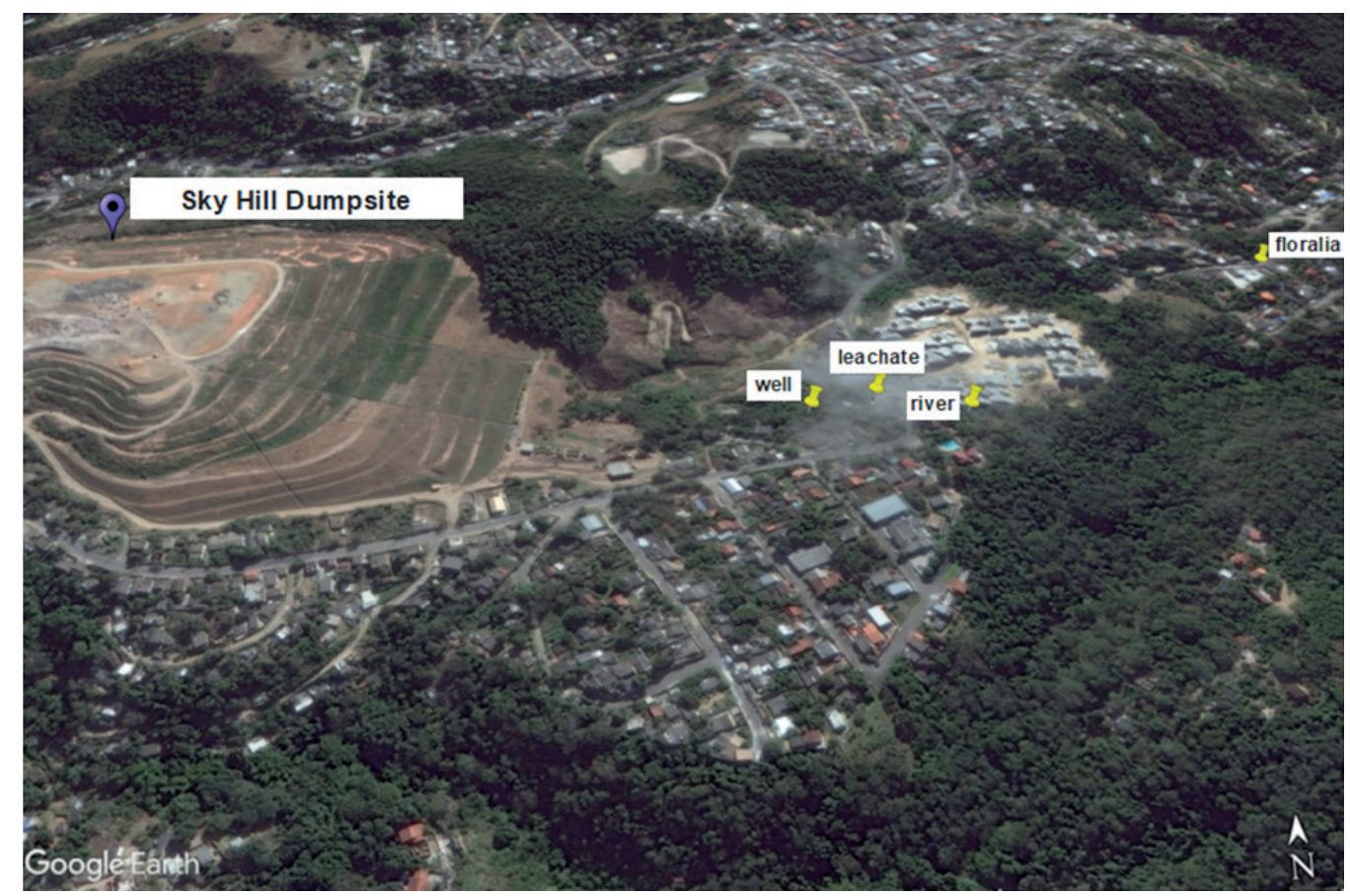

FIGURE 1: Collection points of leachate and water samples: well ( $22^{\circ} 53^{\prime} 32,3^{\prime \prime} \mathrm{S}$ and $\left.43^{\circ} 04^{\prime} 8,80^{\prime \prime} \mathrm{O}\right)$, leachate $\left(22^{\circ} 53^{\prime} 27,0^{\prime \prime} \mathrm{S}\right.$ and $43^{\circ} 03^{\prime}$

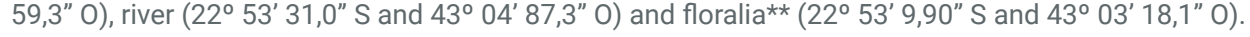

years beforehand, the $\mathrm{pH}$ result was 8.71. Based on the data collected by Souto and Povinelli (2007), this range is within the most probable values for Brazilian landfills. Regarding BOD and COD, in the last analysis performed at the dumpsite, in 2017, the detected values were $255.9 \mathrm{mg} / \mathrm{L}$ and $990 \mathrm{mg} / \mathrm{L}$, respectively. Several authors have reported that the leachate from young landfills is characterized by a very high COD, with values above $2000 \mathrm{mg} / \mathrm{L}$, while in older disposal areas the COD is below $1000 \mathrm{mg} / \mathrm{L}$. Initial- ly, the BOD/COD ratio is typically greater than or equal to 0.5 . Values between 0.4 and 0.6 indicate that the organic matter is readily biodegradable. In mature landfills, this ratio often varies between 0.05 and 0.2 (Ottoni, 2011). In the case of leachate from the Sky Hill dumpsite, the BOD/COD ratio found in 2017 was 0.26 . In relation to surface and groundwater surrounding the landfill, concentrations above the limits established by CONAMA Resolution 357/2005 (5 $\mathrm{mg} / \mathrm{L}$ ) were found for BOD. The highest values were: 790

TABLE 1: Methods of the chemical analyses carried out over the years.

\begin{tabular}{|c|c|c|c|c|c|c|c|c|}
\hline Parameters & 2004 & 2005 & 2006 & 2010 & 2011 & 2012 & 2013 & 2017 \\
\hline COD & \multicolumn{7}{|c|}{ Dichromate in acidic medium - FEEMA 440-R1 } & $\begin{array}{l}\text { Method } 5.220 \text { D, } \\
\text { Closed Reflux - Col- } \\
\text { orimetric. SMEWW, } \\
\text { 20th Edition }\end{array}$ \\
\hline BOD & \multicolumn{6}{|c|}{ Standard method FEEMA MF 439-R1 } & \multicolumn{2}{|c|}{$\begin{array}{l}\text { Method } 5.210 \text { B - Dilutions. } \\
\text { SMEWW, 20th Edition }\end{array}$} \\
\hline $\mathrm{pH}$ & \multicolumn{7}{|c|}{ Potentiometric FEEMA MF 426} & $\begin{array}{l}\text { Method } 4500 \text { B. - } \\
\text { Potentiometric. } \\
\text { SMEWW, 20th } \\
\text { Edition }\end{array}$ \\
\hline $\begin{array}{l}\text { ammoniacal } \\
\text { nitrogens }\end{array}$ & $\begin{array}{l}\text { Determination } \\
\text { of Ammoniacal } \\
\text { Nitrogen by Distil- } \\
\text { lation - CETESB }\end{array}$ & $\begin{array}{l}\text { Potentiometric } \\
\text { with selective } \\
\text { ion - SMEWW / } \\
\text { Phenate standard } \\
\text { method FEEMA } \\
\text { MF } 420\end{array}$ & \multicolumn{4}{|c|}{ Standard method phenate FEEMA MF 420} & \multicolumn{2}{|c|}{$\begin{array}{l}\text { Method 4.500 NH3 F - Indophenol. } \\
\text { SMEWW, 20th Edition }\end{array}$} \\
\hline heavy metals & \multicolumn{6}{|c|}{ Atomic Absorption Spectrometry } & $\begin{array}{l}\text { USEPA 7061-A. 1992 } \\
\text { (Atomic Absorption) } \\
\text { / USEPA 7062. 1994 } \\
\text { (Atomic Absorption) } \\
\text { USEPA 6010-C. 2007; } \\
\text { USEPA 7741-A.1994; } \\
\text { USEPA 7742. 1994; } \\
\text { USEPA 7061-A. 1992; } \\
\text { USEPA 7062. } 1994\end{array}$ & $\begin{array}{l}\text { Optical emission } \\
\text { spectrometer with } \\
\text { inductively coupled } \\
\text { plasma source (ICP } \\
\text { OES)/acid extraction }\end{array}$ \\
\hline
\end{tabular}


$\mathrm{mg} / \mathrm{L}$ and $585 \mathrm{mg} / \mathrm{L}$ at the Floralia and river sites respectively. In 2010, the result in groundwater was $420 \mathrm{mg} / \mathrm{L}$. In all other analyses, the values did not exceed $60 \mathrm{mg} / \mathrm{L}$ and the last result was $19.6 \mathrm{mg} / \mathrm{L}$. As expected for the BOD values, the COD results were also quite high, particularly in the samples collected at the river site in 2011 and 2013. In both years, in periods of high rainfall (January 2013) and low rainfall (September 2011), COD values exceeded 500 $\mathrm{mg} / \mathrm{L}$. For groundwater, COD exceeded $250 \mathrm{mg} / \mathrm{L}$ in January 2013 , but three months later, the values decreased to $81.5 \mathrm{mg} / \mathrm{L}$.

\subsubsection{Ammoniacal Nitrogen}

During the entire monitoring period, the values found for ammoniacal nitrogen in the leachate of dumpsite were well above the established standards, which are $20 \mathrm{mg} / \mathrm{L}$ according to CONAMA Resolution 430/2011 and $5.0 \mathrm{mg} / \mathrm{L}$ according to INEA regulations (NT 202, revision 10). In general, the concentrations of ammoniacal nitrogen in the leachate of Brazilian landfills are very high. At the landfill site in Nova Iguaçu, located in the state of Rio de Janeiro, one of its cells was closed after 7 years of operation, with more than 3 million tons buried. The material received at the site was predominantly organic and the concentrations of ammoniacal nitrogen after its deactivation exceeded 1000 mg /L (Ottoni, 2011). Teixeira et al. (2007) presented analyses of slurry from a garbage dump in the state of Minas Gerais, which operated for 6 years and received about 800 thousand tons of disposed waste. Two years after its closure, the concentrations of ammoniacal nitrogen detected in the leachate exceeded 1,200 mg/L. Queiroz et al. (2011) characterized the leachate generated at the Bandeirantes and São João landfills, both in the state of São Paulo. The former operated for approximately 30 years and received more than 23 million tons of waste. Of this total, approximately $60 \%$ was organic. It was closed in March 2007 and leachate concentrations between May 2008 and February 2009 exceeded 2,390 mg/L. The São João landfill operated between 1992 and 2007 and received approximately 27.9 million tons of urban waste. The amount of leachate generated currently exceeds $1,800 \mathrm{~m}^{3} /$ day and the concentrations of ammoniacal nitrogen measured in the leachate are in the range of 2,870 $\mathrm{mg} / \mathrm{L}$. Lins et al. (2011) reported that the concentrations of ammoniacal nitrogen in the Muribeca landfill in Pernambuco state varied between 1,125 and 2,900 mg/L, which corresponds to the maximum range for Brazilian landfills, according to Souto and Povinelli (2007). In all surface water samples collected near the Sky Hill dumpsite, concentrations were above the limit established by CONAMA, which can vary between 1 and $2 \mathrm{mg} / \mathrm{L}$ depending on the $\mathrm{pH}$ of the medium. In order to evaluate the results of this parameter in groundwater samples, the criteria were used of the Ministry of Health, indicated in Edict 2914/2011, which establishes a consumption acceptance standard of $1.5 \mathrm{mg} / \mathrm{L}$ for non-ionizable ammonia (NH3). In the case of samples collected from the well inside the Sky Hill dumpsite, the $\mathrm{NH} 3$ concentration was 10 times higher than the limit established by this edict in 2011 .

\subsubsection{Heavy Metals}

Slightly higher concentrations of metals are usually found in young landfills due to the high degree of solubilization of metals as a result of the low $\mathrm{pH}$ caused by the production of organic acids. As the age of the landfill increases, $\mathrm{pH}$ values tend to rise, resulting in a drop in metal concentrations, due mainly to the precipitation of hydroxides and sulfides. In the leachate of Sky Hill dumpsite, mean concentrations of $\mathrm{Cd}, \mathrm{Cu}, \mathrm{Ni}, \mathrm{Pb}$ and $\mathrm{Zn}$ remained below the limits established by the legislation in force in all years, with a clear tendency to decrease over time. This behavior confirms the findings of Harmsen (1983) that there are low concentrations of heavy metals in landfill leachates in the fermentation stage due to metallic solubilization and complexation of volatile fatty acids. The average concentrations of the metals $\mathrm{Cr}(\mathrm{VI})$, Fe and $\mathrm{Mn}$ were above the established standards for effluent discharge at the beginning of the monitoring, but in 2017 they were below the allowable limits. The high concentrations of Fe found can be explained by the content of this metal present in the clay used as the cover layer of the Sky Hill dumpsite. The behavior of metals during the monitoring is shown in Figure 2.

The concentrations of heavy metals in surface and groundwater in the vicinity of Sky Hill dumpsite were monitored in order to evaluate the influence of the leachate in these media. At the beginning of the monitoring, with the exception of barium, all other elements were above the maximum limits determined by the regulations in force at the river site. Over the years, the metal concentrations fell and the $\mathrm{Ag}, \mathrm{Ba}, \mathrm{Cr}$ and $\mathrm{Ni}$ levels were below the limits established from 2010 onward. The same happened with $\mathrm{Pb}$ and $\mathrm{Zn}$. Of all the heavy metals monitored in the groundwater well inside the landfill, the only ones that still were above the limits recommended by CONAMA Resolution 420/2009 and Health Ministry Edict 2914/2011 in 2013 were Fe and $\mathrm{Mn}$, which can be explained by the natural composition of the soils of the region.

\subsection{Selection of the parameters to obtain the Deacti- vated Landfill Assessment Index (DLAI)}

In order for the proposed index to be applied in Brazil, the first step was to identify the type of waste that arrives in the largest quantity in landfills. Due to the lack of consolidated initiatives to exploit and recover the organic fraction, at least 70 million tons of this material was buried in 2016 (ABRELPE, 2017). The aggravating factor is that much of this waste goes to landfills that do not have any kind of soil waterproofing, drainage or leachate treatment, causing damage to the health of residents in these areas. For the proposed index, we therefore tried to evaluate the impact caused by the leachate discharge in the water bodies. For the quality of the water supply, for example, high levels of mineral salts, particularly sulfate and chloride, are associated with a tendency for corrosion of distribution systems, in addition to imparting a disagreeable flavor to the water. In order to classify and protect water bodies and to prevent health problems, CONAMA, in Resolutions 357/2005 and 420/2009, establishes maximum permissible values for total dissolved solids (TDS): 


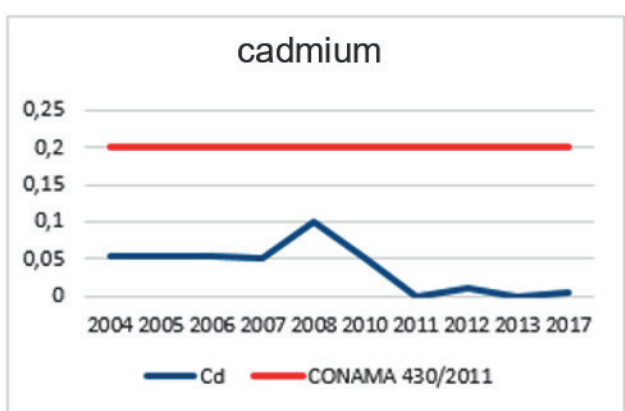

(A)

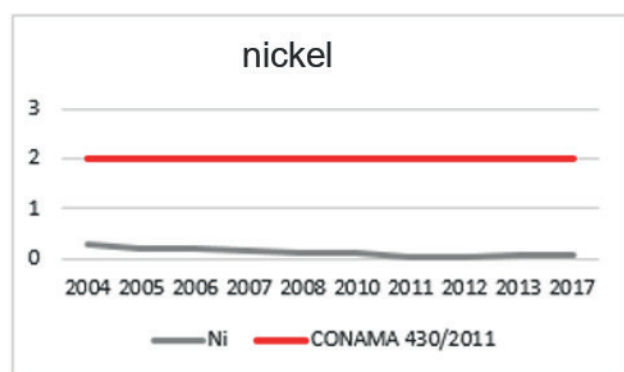

(C)

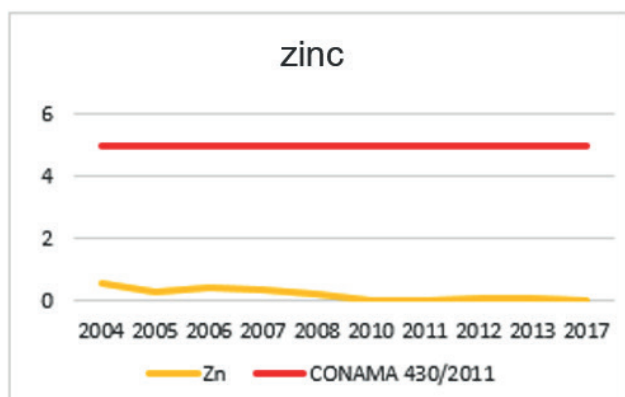

(E)

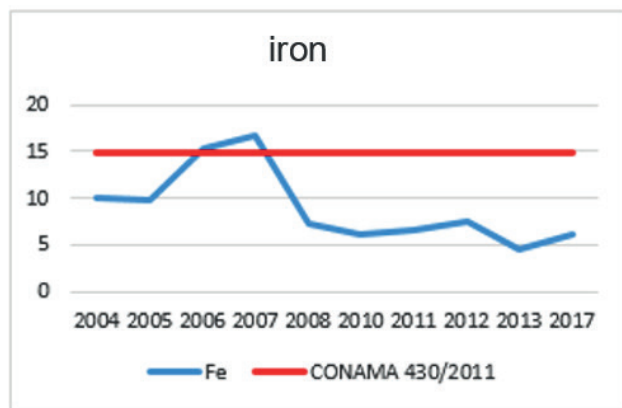

(G)

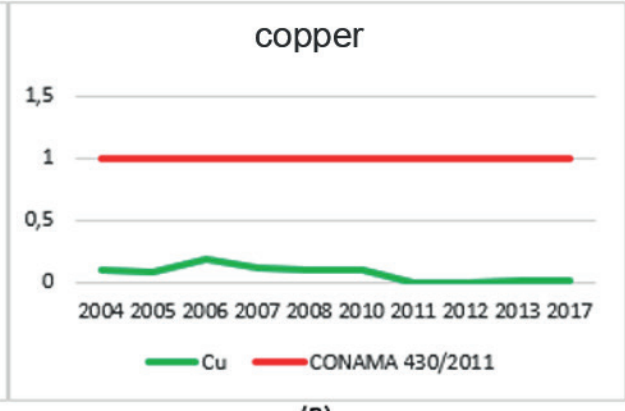

(B)

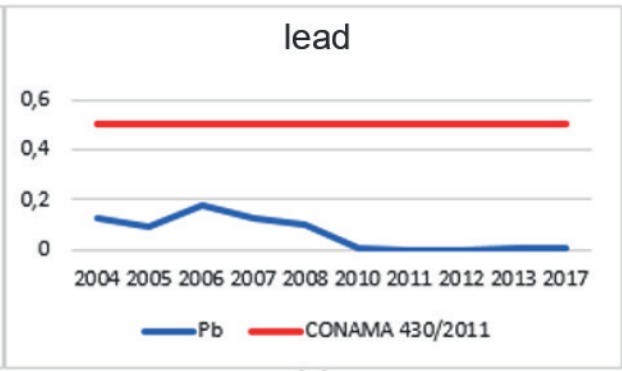

(D)

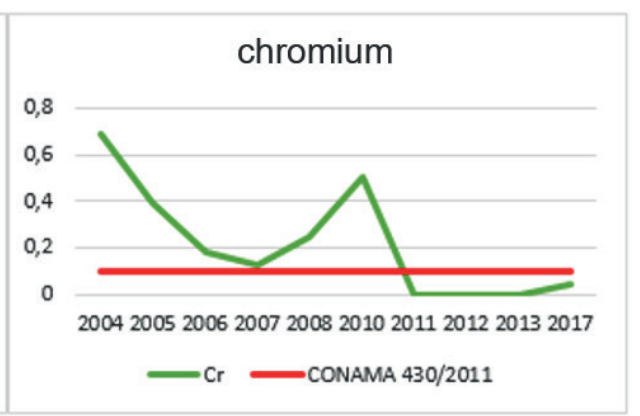

(F)

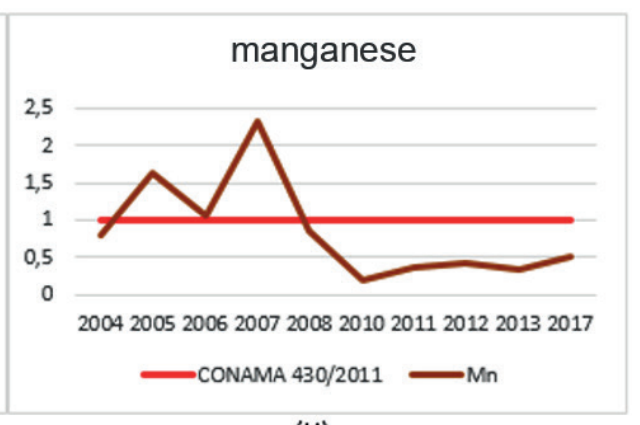

(H)

FIGURE 2: Results of metals in the Sky Hill Dumpsite leachate: (A) cadmium, (B) copper, (C) nickel, (D) lead, (E) zinc, (F) chromium, (G) iron, $(\mathrm{H})$ manganese.

$500 \mathrm{mg} / \mathrm{L}$ for surface water (class 1, 2 and 3) and 1000 $\mathrm{mg} / \mathrm{L}$ for groundwater. Edict 2914/2011 from the Ministry of Health establishes a maximum value of $1000 \mathrm{mg} / \mathrm{L}$ of TDS for water for human consumption. Like for TDS, there are recommendations on the maximum limit of chloride in surface water as well as drinking water (both $250 \mathrm{mg} / \mathrm{L}$ ). The fact is that the dilutive effect of chloride in water bodies generates concentrations normally below $250 \mathrm{mg} / \mathrm{L}$, leading to the belief that it is not a pollutant that can cause long-term problems, and because of this, it should not be considered as an important parameter for assessing the potential contamination from leachate. In addition, chloride and TDS are not even cited in CONAMA Resolution 430/2011, which provides effluent release standards. The same occurs with the coliform and total Kjeldahl nitrogen (TKN) parameters. This means there is no restriction on the release of these compounds, based on the belief that their concentrations will not significantly influence the quality of the water surrounding landfills. Christensen et al. (2001) stated that metals such as As, 
$\mathrm{Cd}, \mathrm{Ni}, \mathrm{Zn}, \mathrm{Cu}, \mathrm{Hg}$ and $\mathrm{Pb}$ do not constitute a frequent problem in landfills containing domestic solid waste. It is therefore believed that for the composition of the pollutant potential of the leachate of deactivated landfill, the parameters related to heavy metals should not be included in the calculation, since their influence on the surroundings of the waste disposal area can be considered low. However, Kumar and Alappat (2003) suggested that metals such as iron ( $w i=0.045)$, copper $(w i=0.050)$, nickel (wi = 0.052), zinc ( $w i=0.052)$, lead ( $w i=0.064)$, mercury (wi $=0.062)$ and arsenic (wi $=0.061)$ had higher weights and importance than $\mathrm{pH}(\mathrm{wi}=0.055)$, ammoniacal nitrogen ( $w i=0.051$ ), and in some cases equal to or greater than BOD (wi = 0.061) and COD (wi = 0.062). The LPI has been applied to several landfills in India, a country where, like in Brazil, organic matter is the main fraction of waste generated. We believe, therefore, that the weights for metals are overestimated, whereas the parameters that have direct relation with the potential pollutant of the organic matter do not receive proper importance in this index. The analysis of the main components of the leachate for predicting the behavior of the organic fraction is a fundamental condition for the creation of an index that can be applied to Brazilian landfills. The data from monitoring the Sky Hill dumpsite and research carried out in other Brazilian landfills indicate that concentrations of heavy metals, phenols, cyanides and chlorides in the leachate tend to fall over time (Teixeira et al. 2007; Ottoni, 2011; Lins et al, 2011; Queiroz et al., 2011). In addition, there is no great influence of these compounds in the water around these disposal areas. On the basis of this finding, we believe it is not necessary for the pollutants mentioned above to be present in the calculation of a leachate pollutant potential assessment index. Among other issues, the excessive number of components to be analyzed to verify polluting potential becomes unnecessary from a technical point of view, in addition to substantially complicating the monitoring. In the case of leachate from Brazilian landfills, we found that the analysis of the concentrations of four components ( $\mathrm{pH}, \mathrm{BOD}, \mathrm{COD}$ and ammoniacal nitrogen) would be enough to evaluate a possible threat of pollution, allowing better allocation of resources for remediation processes. Next, the importance and justification for choosing each of these parameters are highlighted.

\subsection{1 $\mathrm{pH}$}

Farquar and Rovers (1973) found that $\mathrm{pH}$ equal to or lower than 5.5 caused the total inhibition of the production of all gases, which thus corresponds to the total inhibition of the biological activity of the landfill. The concentration of a chemical species found in the leachate can vary depending on the $\mathrm{pH}$ of the sample. For values lower than 7, there may be buffering by volatile acids, which increases the solubility of some heavy metals. The opposite also occurs, since in alkaline media, and especially in environments with high content of organic matter, there may be reduced sulfate levels - since it can precipitate as hydroxides and/ or sulfides, causing the metals to have low solubility. $\mathrm{pH}$ assessment is important, since this parameter affects the activity of enzymes and the toxicity of many compounds.
The most typical example is ammonia. In alkaline media, for example, it is possible to increase its concentration in the non-ionized form $\left(\mathrm{NH}_{3}\right)$, which is toxic.

\subsubsection{Ammoniacal Nitrogen}

Waste landfills, because they are predominantly anaerobic environments, produce effluents with very low concentrations of nitrites and nitrates. On the other hand, the strong biological activity present in both the residue mass and the drainage system causes almost all of the organic nitrogen to be converted into ammoniacal nitrogen inside the landfill itself, and it is not used in significant quantities by any microbial group. Thus, there are high concentrations of ammonia in the leachate, considered an important tracer in the contamination of the water bodies (Souto and Povinelli, 2007). The oldest landfill leachate is typically rich in ammoniacal nitrogen due to the hydrolysis and fermentation of the nitrogenous fractions of biodegradable substrates. Free ammonia $\left(\mathrm{NH}_{3}\right)$ is a very restrictive toxic substance to fish, and many species cannot withstand concentrations above $5 \mathrm{mg} / \mathrm{L}$. For these reasons, the concentration of ammoniacal nitrogen is an important parameter for the classification of natural water bodies and is usually used in the constitution of water quality indexes (CETESB, 2009). Clément and Merlin (1995) argued that alkalinity and ammonia may be the main contributors to the toxicity attributed to leachate. In addition to compromising the quality of drinking water, in the short term human exposure to ammonia can cause severe burns to the skin, eyes, throat, lungs, mouth and stomach. In case of prolonged exposure, liver diseases, chronic respiratory problems and glaucoma are some of the maladies caused by this pollutant. In the case of enclosed landfills, and those with heightened risks because they are near rivers or important aquifers, the attention paid to this pollutant must be greater than for any other.

In the LPI, an index proposed by Kumar and Alappat (2003), the weight given to ammoniacal nitrogen is very low ( $w i=0.051)$ compared to its importance in Brazilian or even Indian landfills, studied by Bhalla et al. (2014), Krishnamurthy et al. (2015) and Naveen et al. (2016). The organic matter is the predominant material in the mass of garbage, so ammoniacal nitrogen, whose concentration rises with the passage of time, should receive greater weight when calculating the index of polluting potential of Brazilian leachate. This means that, based on all the information presented on the impacts not only on the environment but also health, this parameter should be seen as the most important when assessing the need for remediation of an area.

\subsubsection{BOD and $C O D$}

The high organic matter load present in leachate, due to the indiscriminate disposal of organic residues in landfills, can cause water pollution due to the consumption of dissolved oxygen by the microorganisms in their metabolic processes of using and stabilizing organic matter. In the choice of the parameters for composition of a new index for the classification of leachate from depleted landfills, in addition to ammoniacal nitrogen and $\mathrm{pH}, \mathrm{BOD}$ and $\mathrm{COD}$ should also be considered, since the quantification of or- 
ganic matter and its pollutant potential is traditionally evaluated through these methods. In addition, the BOD/COD ratio is considered a good indicator of the level of biological degradation of the effluent. Depending on the magnitude of this ratio, one can draw conclusions about the biodegradability of the waste, and from this forecast the necessary monitoring time. A high BOD/COD ratio signals the presence of a biodegradable fraction whereas a ratio less than 0.1 has been suggested as an indicator of stable leachate (Reinhart and Townsend, 1997; Barlaz et al., 2002). It is important to note that, like ammoniacal nitrogen, the parameters BOD and COD have important weights because the proposed index is tailored for application to Brazilian landfills. In addition, $\mathrm{pH}$ should also be considered when calculating the index, since depending on the alkalinity of the environment, the predominance of heavy metals can be evaluated.

\subsection{Statistical analysis of results}

The Statistica 7 program was used for statistical analysis of the results obtained from the landfill monitoring. Initially, descriptive statistics were used to summarize the data relating to all compounds analyzed in the leachate in a direct manner: mean, minimum and maximum values, standard deviation, etc. From the normalization of the data obtained through the annual averages of monitoring the leachate at the Sky Hill dumpsite, Pearson correlation coefficients were calculated, as presented in Table 2.

When analyzing the matrix, it is possible to see that although the $\mathrm{pH}$ had a negative correlation with most of the variables, this parameter was not the only one that directly influenced the availability of metals. All metals varied inversely in relation to $\mathrm{pH}$ (negative values, as expected), but the correlations were low. Probably the greater variation of the metals is related to the presence of organic matter. In the same matrix, it is possible to note a high positive correlation between the metals, which may indicate they are associated with the same source. In the case of the Sky Hill dumpsite, we believe that metals come from industrial waste, since at the beginning of the operation there was no control over the material that came to the site. The statistics also show that BOD and COD, as expected, presented high positive correlation.

Multivariate statistical analysis (main components and cluster) was used both to describe the similarity between the samples considering the total set of variables and their correlations, and to find sets of variables that can be considered redundant. Principal component analysis (PCA) made it possible to transform the data into two dimensions. Factor 1 involved the elements $\mathrm{Pb}, \mathrm{Cu}, \mathrm{Fe}, \mathrm{Ni}, \mathrm{Zn}$, phenols, cyanides and BOD and COD, influencing $48.69 \%$ of the sample as a whole. Although $\mathrm{pH}$ is not present in factors 1 and 2, it has an important influence on the other variables, since factor 3 , which includes $\mathrm{pH}$, influences $11 \%$ of the sample as a whole. In Figure 3 it is possible to visualize the table with the main factors and also the projection of the variables in the plane. Figure 4 shows the importance of each factor in the sample as a whole.

Through the dendrograms presented below, it is possible to recognize patterns (similarities) between samples

TABLE 2: Correlation Matrix (leachate variables).

\begin{tabular}{|c|c|c|c|c|c|c|c|c|c|c|c|c|c|c|c|c|c|c|}
\hline & ${\frac{T^{+}}{Z}}^{+}$ & ๓ & J & $\frac{0}{2}$ & $\overline{\mathcal{U}}$ & ¿ & $\sum$ & $\bar{z}$ & 电 & $\bar{N}$ & $\begin{array}{l}\frac{\infty}{0} \\
\frac{0}{0} \\
\frac{\bar{c}}{2}\end{array}$ & $\sum_{0}$ & 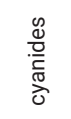 & $\frac{\mathscr{0}}{\frac{0}{0}}$ & రి & ठ̊ & $\begin{array}{l}\text { Oे } \\
\text { Oे } \\
\text { Oे }\end{array}$ & $\frac{T}{2}$ \\
\hline $\mathrm{NH}_{4}$ & 1.00 & & & 0.72 & 0.67 & & 0.38 & & 0.53 & 0.61 & 0.33 & 0.26 & 0.32 & 0.09 & 0.49 & 0.61 & -0.11 & -0.18 \\
\hline $\mathrm{Ba}$ & 0.19 & 1.00 & 0.16 & 0.28 & 0.38 & 0.50 & 0.26 & -0.26 & 0.62 & -0.07 & -0.48 & -0.42 & -0.03 & 0.18 & -0.55 & 0.04 & 0.83 & -0.52 \\
\hline $\mathrm{Cd}$ & 0.60 & 0.16 & 1.00 & 0.70 & 0.77 & 0.38 & 0.42 & 0.54 & 0.31 & 0.51 & 0.50 & 0.64 & 0.39 & -0.10 & 0.39 & 0.37 & 0.16 & -0.31 \\
\hline $\mathrm{Pb}$ & 0.72 & 0.28 & 0.70 & 1.00 & 0.89 & 0.84 & 0.68 & 0.81 & 0.79 & 0.88 & 0.62 & 0.42 & 0.68 & -0.37 & 0.58 & 0.73 & 0.06 & -0.16 \\
\hline $\mathrm{Cu}$ & 0.67 & 0.38 & 0.77 & 0.89 & 1.00 & 0.75 & 0.55 & 0.70 & 0.78 & 0.67 & 0.48 & 0.55 & 0.62 & -0.21 & 0.40 & 0.55 & 0.00 & -0.28 \\
\hline $\mathrm{Fe}$ & 0.48 & 0.50 & 0.38 & 0.84 & 0.75 & 1.00 & 0.82 & 0.62 & 0.93 & 0.71 & 0.37 & 0.13 & 0.69 & -0.40 & 0.20 & 0.47 & -0.24 & -0.13 \\
\hline $\mathrm{Mn}$ & 0.38 & 0.26 & 0.42 & 0.68 & 0.55 & 0.82 & 1.00 & 0.54 & 0.67 & 0.56 & 0.46 & 0.11 & 0.80 & -0.39 & 0.19 & 0.42 & -0.19 & -0.09 \\
\hline $\mathrm{Ni}$ & 0.51 & -0.26 & 0.54 & 0.81 & 0.70 & 0.62 & 0.54 & 1.00 & 0.47 & 0.93 & 0.88 & 0.74 & 0.68 & -0.43 & 0.83 & 0.70 & 0.46 & 0.08 \\
\hline $\mathrm{Ag}$ & 0.53 & 0.62 & 0.31 & 0.79 & 0.78 & 0.93 & 0.67 & 0.47 & 1.00 & 0.55 & 0.18 & -0.01 & 0.62 & -0.31 & 0.13 & 0.49 & -0.33 & -0.15 \\
\hline $\mathrm{Zn}$ & 0.61 & -0.07 & 0.51 & 0.88 & 0.67 & 0.61 & 0.56 & 0.93 & 0.55 & 1.00 & 0.81 & 0.55 & 0.63 & -0.35 & 0.78 & 0.75 & 0.29 & -0.05 \\
\hline phenols & 0.33 & -0.48 & 0.50 & 0.62 & 0.48 & 0.37 & 0.46 & 0.88 & 0.18 & 0.81 & 1.00 & 0.74 & 0.73 & -0.34 & 0.85 & 0.63 & 0.53 & 0.04 \\
\hline CrVI & 0.26 & -0.42 & 0.64 & 0.42 & & 0.13 & 0.11 & 0.74 & 0.01 & 0.55 & & 1.00 & 0.34 & -0.11 & 0.63 & 0.30 & 0.57 & -0.07 \\
\hline cyanides & 0.38 & -0.03 & 0. & 0.68 & 0.62 & 0.69 & 0.80 & 0.68 & 0.62 & 0.63 & 0.73 & 0.34 & 1.00 & -0.38 & 0.49 & 0.58 & 0.10 & -0.02 \\
\hline fluorides & 0.09 & 0.18 & -0.10 & -0.37 & -0.21 & -0.40 & -0.39 & -0.43 & -0.31 & -0.35 & -0.34 & -0.11 & -0.38 & 1.00 & -0.28 & 0.09 & -0.45 & -0.72 \\
\hline BOD & 0.49 & -0.55 & 0.39 & 0.58 & 0.40 & 0.20 & 0.19 & 0.83 & 0.13 & 0.78 & 0.85 & 0.63 & 0.49 & -0.28 & 1.00 & 0.80 & 0.64 & 0.14 \\
\hline COD & 0.61 & -0.04 & 0.37 & 0.73 & 0.55 & 0.47 & 0.42 & 0.70 & 0.49 & 0.75 & 0.63 & 0.30 & 0.58 & -0.09 & 0.80 & 1.00 & 0.07 & -0.25 \\
\hline BOD/COD & 0.11 & -0.83 & 0.16 & 0.06 & 0.00 & -0.24 & -0.19 & 0.46 & -0.33 & 0.29 & 0.53 & 0.57 & 0.10 & -0.45 & 0.64 & 0.07 & 1.00 & 0.69 \\
\hline $\mathrm{pH}$ & -0.18 & -0.52 & -0.31 & -0.16 & -0.28 & -0.13 & -0.09 & 0.08 & -0.15 & -0.05 & 0.04 & -0.07 & -0.02 & -0.72 & 0.14 & 0.25 & 0.69 & 1.00 \\
\hline
\end{tabular}




\begin{tabular}{|c|c|c|}
\hline Variable & Factor 1 & Factor 2 \\
\hline $\mathrm{NH} 4$ & 0.675720 & 0.185894 \\
\hline $\mathrm{Ba}$ & 0.026212 & 0.963402 \\
\hline $\mathrm{Cd}$ & 0.675947 & 0.071495 \\
\hline $\mathrm{Pb}$ & 0.952967 & 0.216119 \\
\hline $\mathrm{Cu}$ & 0.851104 & 0.301330 \\
\hline $\mathrm{Fe}$ & 0.773735 & 0.485678 \\
\hline $\mathrm{Mn}$ & 0.698006 & 0.342253 \\
\hline $\mathrm{Ni}$ & 0.927381 & -0.291831 \\
\hline $\mathrm{Ag}$ & 0.681202 & 0.600196 \\
\hline $\mathrm{Zn}$ & 0.925041 & -0.109274 \\
\hline phenols & 0.801454 & -0.468198 \\
\hline $\mathrm{Cr} \mathrm{VI}$ & 0.588731 & -0.481236 \\
\hline cyanides & 0.797191 & 0.045155 \\
\hline fluorides & -0.385535 & 0.296797 \\
\hline $\mathrm{BOD}$ & 0.726054 & -0.565358 \\
\hline $\mathrm{COD}$ & 0.767273 & -0.000373 \\
\hline BOD/COD & 0.236218 & -0.917403 \\
\hline $\mathrm{pH}$ & -0.085108 & -0.599637 \\
\hline Expl. Var & 8.764353 & 3.977426 \\
\hline Prp.Totl & 0.486909 & 0.220968 \\
\hline & &
\end{tabular}

(A)

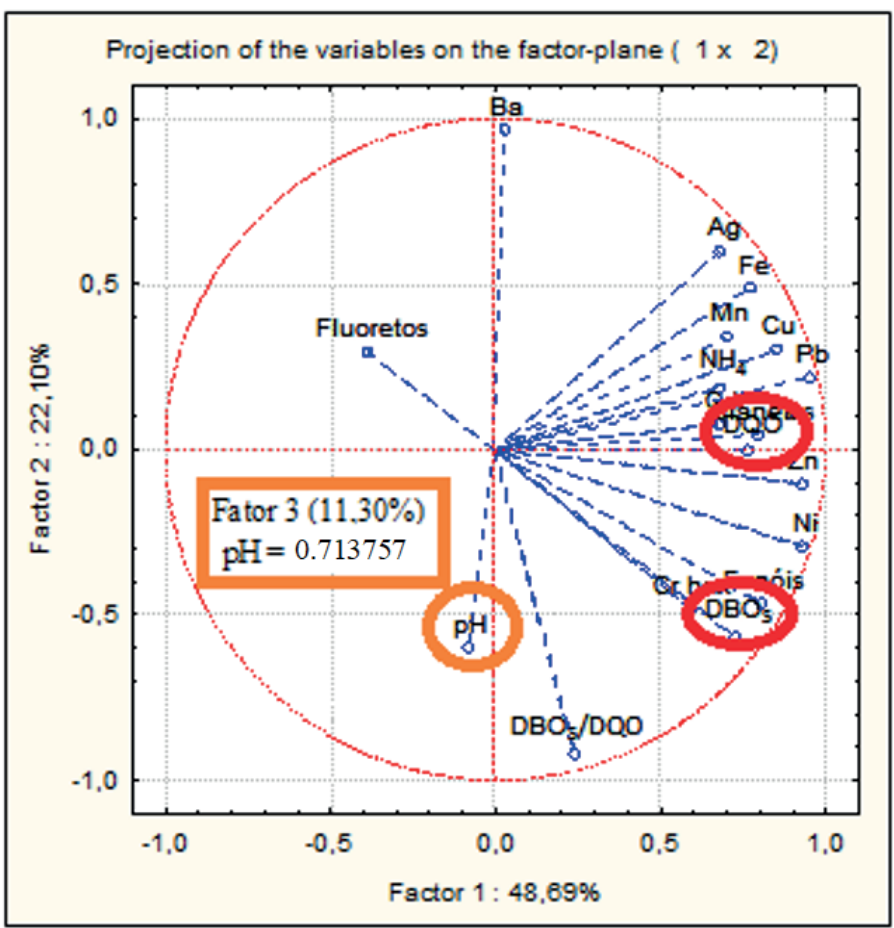

(B)

FIGURE 3: (A) Factor 1 and Factor 2 (ACP); Projection of the variables in the plane (detail for BOD and COD - Factor 1 and pH - Factor 3).

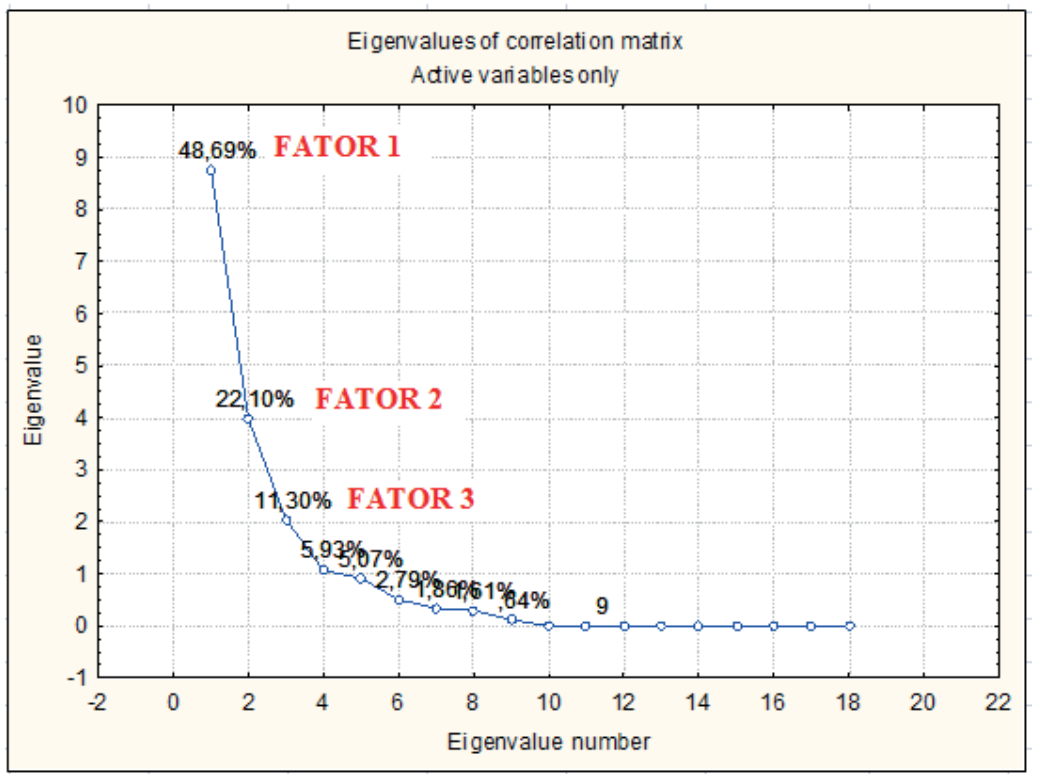

FIGURE 4: Factors 1, 2 and 3 of principal component analysis.

from a set of data, allowing the grouping of samples among them. The smaller the distance is between the points, the greater the similarity between the samples is.

\subsubsection{Dendrogram (years)}

In the first dendrogram (Figure 5a), two large groups of similarity are formed. The first, formed by the initial years 2004, 2005, 2006 and 2007, jibes with the history of the area, since the site was operated as a dump during this period. The second group, formed by the years 2008, 2010, 2011, 2012, 2013 and 2017, indicates that with the beginning of control of the landfill, the area began to present similar behavior in 2008 .

\subsubsection{Dendrogram (variables)}

In the second dendrogram, two large groups of similarity are formed (Figure $5 \mathrm{~b}$ ). The first is formed by the metals $\mathrm{Mn}, \mathrm{Ag}, \mathrm{Fe}, \mathrm{Cu}, \mathrm{Pb}$ and $\mathrm{Cd}$, along with cyanides, fluorides 


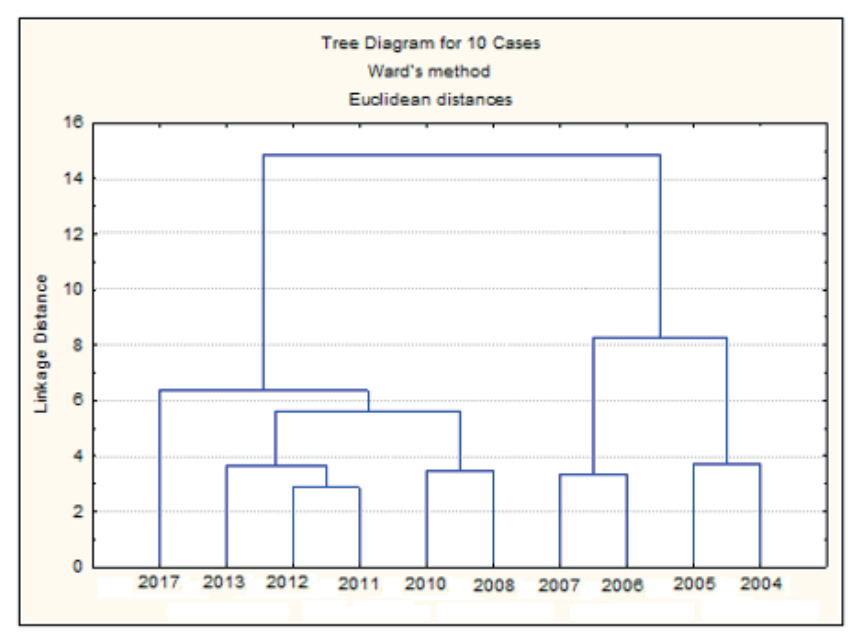

(a)

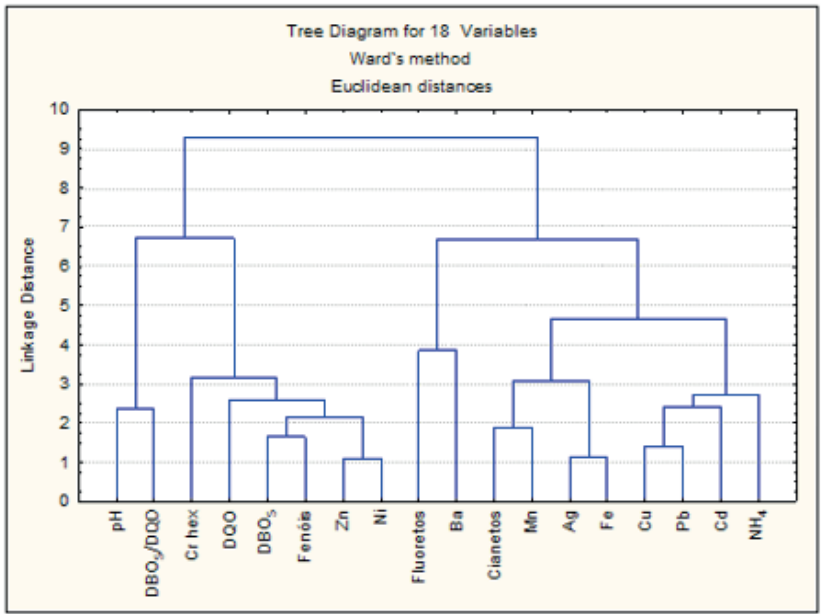

(b)

FIGURE 5: (a) Dendrogram of the years of operation, (b) Dendrogram of the variables.

and ammoniacal nitrogen. These results indicate greater similarity in the behavior of metals, cyanide and ammoniacal nitrogen, as well as greater similarity in the behavior of fluorides with barium, indicating they probably come from the same source. The second group is formed by BOD, $\mathrm{COD}, \mathrm{Zn}, \mathrm{Ni}$, phenols, $\mathrm{Cr}(\mathrm{VI}), \mathrm{BOD} / \mathrm{COD}$ ratio and $\mathrm{pH}$. There is strong similarity between the $\mathrm{pH}$ and the BOD/COD.

$D$ ratio, indicating that the behavior of the sample as a whole was directly influenced by the associated action of these two parameters. The phenols are associated, as expected, with BOD, COD, $\mathrm{Zn}$ and $\mathrm{Ni}$. As in the correlation matrix, there is a high positive correlation between the elements $\mathrm{Zn}$ and $\mathrm{Ni}$, which suggests they come from the same source.

\subsection{Distribution of weights of the parameters cho- sen for DLAI calculation}

For the four parameters cited, weights were assigned according to the potential impacts of these components on the environment and human health, in addition to treatment costs, as in the case of ammoniacal nitrogen. Therefore, we believe this parameter should receive the greatest weight among the four chosen to compose the index. Regarding $\mathrm{pH}, \mathrm{BOD}$ and $\mathrm{COD}$, we decided to distribute the same weights for the three parameters, all smaller than the one suggested for ammoniacal nitrogen, which is the greatest concern when analyzing deactivated waste disposal areas. Its presence at high concentrations throughout the life of the landfill makes it one of the main pollut-

TABLE 3: Weights of pollutants in the Deactivated Landfill Assessment Index (DLAI).

\begin{tabular}{c|c} 
Pollutant & Weight $\left(\mathbf{w}_{\mathbf{i}}\right)$ \\
\hline $\mathrm{pH}$ & 0,15 \\
$\mathrm{BOD}$ & 0,15 \\
$\mathrm{COD}$ & 0,15 \\
\hdashline Ammoniacal nitrogen & 0,55 \\
\hline Total & 1 \\
\hline
\end{tabular}

ants in leachate. According to Chu et al. (1994), after a period of 3 to 8 years, the concentration of ammoniacal nitrogen reaches values between 500 and $1500 \mathrm{mg} / \mathrm{L}$, remaining at this level for at least 50 years. We believe that for a first analysis, shortly after the closure of a landfill, it is important to assess a wider range of pollutants present in the leachate, just to verify that the behavior of the area is in line with what is expected (low concentrations of metals, for example) and within the limits established in the standards with respect to leachate release. If the levels are below the limits, the monitoring can be continued only with the evaluation of the most relevant parameters, presented in Table 3, which were weighted for the calculation of the Deactivated Landfill Assessment Index (DLAI).

Despite the need to create a new index, where the weights and the individual importance of each parameter were changed to fit the reality of Brazilian landfills, the curves presented by Kumar and Alappat (2005) (Figure 6) are useful for determining the sub-index components analyzed.

Thus, the DLAI can be calculated using equation 1:

$D L A I=\sum_{i=1}^{n} w_{i} p_{i} \quad \sum_{i=1}^{n} w_{i}=1$

where: DLAI - Deactivated Landfill Assessment Index; wi - weight of the parameter evaluated;

pi - score of the sub-index of the parameter evaluated;

$\mathrm{n}$ - number of pollutant variables of the leachate used in calculating the DLAI.

The procedure for calculating the DLAI for the leachate must follow the three steps below:

1. Analysis of the 4 parameters ( $\mathrm{pH}, \mathrm{BOD}, \mathrm{COD}$ and ammoniacal nitrogen).

2. Determination of the 'pi' subscript values from the curves presented by Kumar and Alappat (2005), based on the concentration of leachate pollutants (Figure 7).

3. Aggregation of 'pi' subscript values obtained for the parameters, multiplied by the respective 'wi' weights assigned to each parameter. The weighted sum of all parameters gives the DLAI. 

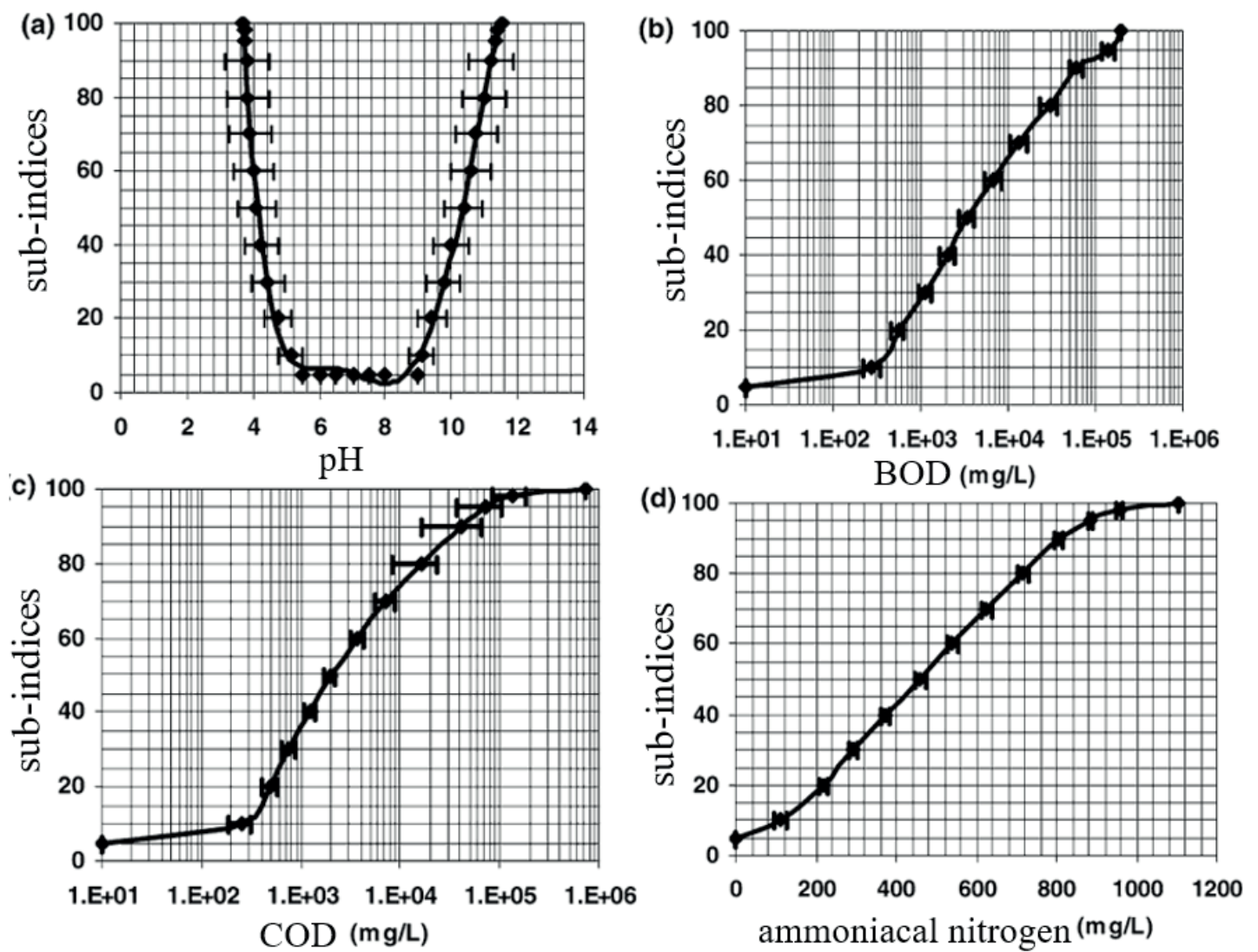

FIGURE 6: Subscript curves of (a) pH, (b), BOD, COD and ammoniacal nitrogen (Kumar and Alappat, 2005).

Like the LPI, the DLAI is represented by a number ranging from 5 to 100 (as a score), expressing the overall contamination potential of the leachate from a landfill based on the defined parameters. It is an increasing scale index, where a higher value indicates greater potential for contamination by the leachate.

\subsection{Calculation of the DLAI for the Sky Hill dumpsite}

The LPI value was calculated for the leachate at the Sky Hill dumpsite using the method proposed by Kumar and Alappat (2005), with weights distributed in 12 parameters (Table 4). Then, the calculations were redone with the weights proportional to the importance of the organic fraction in Brazilian landfills, taking into account $\mathrm{pH}, \mathrm{BOD}$, COD and ammoniacal nitrogen. In this new calculation, therefore, the contributions of heavy metals, chlorides, TDS and others were not considered, because they did not directly influence the contamination of the water around the landfill. In analyzing Table 5, it is possible to verify that the calculation of the DLAl for the leachate through the application of the method proposed for Brazilian landfills provides values with relevant changes. The pollutant potential of Sky Hill dumpsite, calculated with new parameters and weights, comes close to that in $2004(\mathrm{LPI}=17.68, \mathrm{DLAl}=$ 62.70) and 2006 (LPI = 17.94, DLAI = 64.55), quadrupled when compared to the LPI in the same year. If the DLAI were also applied in the deactivated landfills studied by Kumar and Alappat (2005) in Hong Kong and by Umar et al. (2010) in Malaysia, the results of these indexes would also be quite different. In the case of the first study cited, the LPI values were 45.01 for the Ma Tso Lung (MTL) landfill and 15.97 for the Nagu Chi Wan (NCW). If the DLAl were applied to these landfills, the values would rise to 81.25 and 52.90 , respectively. In the landfill evaluated by Umar et al. (2010), the value of the index would increase $46 \%$ if it were calculated from the parameters and weights suggested for the DLAI. The results found for the DLAI suggest that the pollutant potential of the leachate is much higher when one considers the parameters that really contribute most relevantly to the prolonged activity of the landfills. Calculation of the DLAI can assist in the first phase of low-cost landfill closure and recovery projects. The application of this index in waste disposal areas in Brazil can serve as a tool to prioritize remediation processes, by assessing which areas should undergo immediate intervention.

\section{CONCLUSIONS}

Organic matter is mainly responsible for the prolongation of the activity of a landfill, which means that $\mathrm{pH}, \mathrm{BOD}$, COD and ammoniacal nitrogen are the main parameters for the composition of a landfill closure assessment index. From the application of the LPI in Brazilian landfills, it was verified that the importance given to leachate components was not adequate. The DLAI was proposed to consider the conditions in the country and the garbage produced and buried, by assigning weights to each parameter according to the verification of the potential impacts of these components on the environment, human health and treatment 
TABLE 4: Average values of the analyzed parameters in the Sky Hill leachate during the monitoring.

\begin{tabular}{|c|c|c|c|c|c|c|c|c|c|c|c|}
\hline & Parameters & 2004 & 2005 & 2006 & 2007 & 2008 & 2010 & 2011 & 2012 & 2013 & 2017 \\
\hline 1 & $\mathrm{pH}$ & 7.960 & 7.960 & 7.830 & 7.680 & 7.610 & 7.670 & 7.720 & 7.790 & 7.680 & 8.710 \\
\hline 2 & $\mathrm{BOD}(\mathrm{mg} / \mathrm{L})$ & 568,940 & 428,080 & 382,440 & 210,530 & 296,600 & 195,000 & 182,000 & 163,900 & 350,250 & 255,900 \\
\hline 3 & $\mathrm{COD}(\mathrm{mg} / \mathrm{L})$ & $2,101,630$ & $1,876,250$ & $2,166,330$ & $1,684,080$ & $1,580,000$ & $1,020,000$ & $1,276,100$ & 969,270 & $2,051,500$ & 990,000 \\
\hline 4 & $\mathrm{NH}_{4}(\mathrm{mg} / \mathrm{L})$ & 855,440 & 795,500 & 975,330 & 846,220 & 927,000 & 723,100 & 492,870 & 788,090 & 841,600 & 706,200 \\
\hline
\end{tabular}

TABLE 5: Comparison between LPI and DLAI values for each year of monitoring.

\begin{tabular}{|c|c|c|c|c|c|c|c|c|c|c|c|c|c|c|c|c|c|c|c|c|c|}
\hline \multirow{2}{*}{ Parameters } & \multirow{2}{*}{ Weight (wi) } & \multicolumn{2}{|c|}{2004} & \multicolumn{2}{|c|}{2005} & \multicolumn{2}{|c|}{2006} & \multicolumn{2}{|c|}{2007} & \multicolumn{2}{|c|}{2008} & \multicolumn{2}{|c|}{2010} & \multicolumn{2}{|c|}{2011} & \multicolumn{2}{|c|}{2012} & \multicolumn{2}{|c|}{2013} & \multicolumn{2}{|c|}{2017} \\
\hline & & $\mathrm{Pi}$ & pi*wi & $\mathbf{P i}$ & $p^{* *} w i$ & pi & $p^{*}{ }^{\star} w i$ & pi & $p^{{ }^{\star}}{ }^{w i}$ & pi & $p^{*}{ }^{\star} w i$ & pi & $p i^{\star} w i$ & pi & $p i^{\star} w i$ & pi & $p^{i * w i}$ & pi & $p i^{\star} w i$ & pi & $p^{*}{ }^{\star} w i$ \\
\hline $\mathrm{pH}$ & 0.15 & 5 & 0.75 & 5 & 0.75 & 5 & 0.75 & 5 & 0.75 & 5 & 0.75 & 5 & 0.75 & 5 & 0.75 & 5 & 0.75 & 5 & 0.75 & 5 & 0.75 \\
\hline BOD & 0.15 & 20 & 3.00 & 15 & 2.25 & 13 & 1.95 & 10 & 1.50 & 10 & 1.50 & 9 & 1.35 & 9 & 1.35 & 9 & 1.35 & 12 & 1.80 & 10 & 1.50 \\
\hline COD & 0.15 & 52 & 7.80 & 46 & 6.90 & 53 & 7.95 & 45 & 6.75 & 41 & 6.15 & 35 & 5.25 & 37 & 5.55 & 35 & 5.25 & 51 & 7.65 & 35 & 5.25 \\
\hline $\mathrm{NH}_{4}$ & 0.55 & 93 & 51.15 & 89 & 48.95 & 98 & 53.90 & 93 & 51.15 & 97 & 53.35 & 83 & 45.65 & 49 & 26.95 & 88 & 48.40 & 92 & 50.60 & 79 & 43.45 \\
\hline LPI & $\begin{array}{l}12 \text { parame- } \\
\text { ters * }\end{array}$ & \multicolumn{2}{|c|}{17.68} & \multicolumn{2}{|c|}{17.24} & \multicolumn{2}{|c|}{17.94} & \multicolumn{2}{|c|}{16.39} & \multicolumn{2}{|c|}{16.07} & \multicolumn{2}{|c|}{14.29} & \multicolumn{2}{|c|}{11.64} & \multicolumn{2}{|c|}{14.4} & \multicolumn{2}{|c|}{16.45} & \multicolumn{2}{|c|}{15.62} \\
\hline DLAI & $\begin{array}{c}4 \text { parame- } \\
\text { ters }\end{array}$ & \multicolumn{2}{|c|}{62.70} & \multicolumn{2}{|c|}{58.85} & \multicolumn{2}{|c|}{64.55} & \multicolumn{2}{|c|}{60.15} & \multicolumn{2}{|c|}{61.75} & \multicolumn{2}{|c|}{53.00} & \multicolumn{2}{|c|}{34.60} & \multicolumn{2}{|c|}{55.75} & \multicolumn{2}{|c|}{60.80} & \multicolumn{2}{|c|}{50.95} \\
\hline
\end{tabular}

* Weights proposed by Kumar and Alappat, 2005

** New weights

expenses. It was possible to conclude from the statistical analysis that the parameters BOD, COD and $\mathrm{pH}$ are important variables, with strong influence on the dataset, thus justifying their presence in the index. As expected, in the principal component analysis (PCA), the elements $\mathrm{Pb}, \mathrm{Cu}$, $\mathrm{Fe}, \mathrm{Ni}, \mathrm{Zn}$, phenols, cyanides and BOD and COD, influence the sample as a whole. $\mathrm{pH}$ it has an important influence of the sample as a whole. Taking into account the lack of criteria to support decisions regarding the allocation of resources for remediation processes, the application of the DLAI can technically support the formulation of municipal actions for management and control of landfills, especially in the post-closure phase.

\section{ACKNOWLEDGMENTS}

The authors would like to thank CAPES, CNPq and FAPERJ for supporting this study.

\section{REFERENCES}

ABRELPE - BRAZILIAN ASSOCIATION OF PUBLIC CLEANING AND SPECIAL WASTE. COMPANIES. Overview of Solid Waste in Brazil. 2015 Edition. São Paulo. 2015. Available at: <http://www.abrelpe.org.br/ Panorama/panorama2015.pdf>. Accessed on: 20 Nov. 2016.

Barlaz, M.A., Rooker, A.P., Kjeldsen, P., Gabr, M.A., Borden, R.C., 2002. Critical Evaluation of Factors Required to Terminate the Postclosure Monitoring Period at Solid Waste Landfills. Environmental Science Technology, v. 36, p. 3457-3464.

Bhalla, B., Saini, M.S., Jha, M.K., 2014. Leachate contamination potential of unlined municipal solid waste landfill sites by leachate pollution index. International Journal of Science, Environment and Technology, v. 3, n. 2, p. 444-457

CETESB - ENVIRONMENTAL COMPANY OF THE STATE OF SÃO PAULO. Manual of management of contaminated areas. São Paulo, 2009. Available at: <http://www.cetesb.sp.gov.br/areas-contaminadas/ manual-de-garagem-de-ACs/7>. Accessed on: 5 Aug. 2015.

Christensen, T.H., Kjeldsen, P., Bjerg, P.L., Jensen, D.L., Christensen, J.B., Baun, A., Albrechtsen, H., Heron, G., 2001. Biogeochemistry of landfill leachate plumes. Applied geochemistry, v. 16, n. 7, p. 659-718.
Chu, L.M., Cheung, K.O., Wong, M.H., 1994. Variations in the chemical properties of landfill leachate. Environmental Management. v. 18, No. 1, pp. 105-117, 1994.

Clément, B., Merlin, G., 1995. The contribution of ammonia and alkalinity to landfill leachate toxicity to duckweed. Science of the Total Environmental. v. 170, n. 1-2, p. 71-79.

CONAMA - NATIONAL (BRAZILIAN) COUNCIL FOR THE ENVIRONMENT. Resolution No. 357, dated March 17, 2005, which provides the classification of water bodies and environmental guidelines for their classification, as well as establishing the conditions and standards for effluent discharge, and other matters. Available at: <http://www.mma.gov.br/port/conama/legiabre.cfm?codlegi=459> Accessed on: 28 Oct. 2015.; Resolution No. 420, dated December 28, 2009, which provides criteria and parameters of soil quality due to the presence of chemical substances and establishes guidelines for the environmental management of areas contaminated by these substances as a result of anthropic activities. Available at: <http://www.mma.gov.br/port/conama/legiabre. cfm?codlegi=620> Accessed on: 28 Oct. 2015.; Resolution No. 430 of 13 May 2011, supplements and amends Resolution No. $357 / 2005$ on the conditions and standards for the discharge of effluents. Available at: <http://www.mma.gov.br/port/conama/legiabre.cfm?codlegi=646> Accessed on: 2 Nov. 2016. (In Portuguese)

Farquhar, G.J., ROVERS, F.A., 1973. Gas production during refuse decomposition. Water, Air, \& Soil Pollution. v. 2, p. 483-495.

Harmsen, J., 1983. Identification of Organic Compounds in Leachate from a Waste Tip, Water Research, V. 17, No. 6, p. 699-705.

IBGE - BRAZILIAN INSTITUTE OF GEOGRAPHY AND STATISTICS, 2015. Available at: <http://cidades.ibge.gov.br/xtras/perfil. php?codmun=510340 > Accessed on: 11 Aug. 2016.

INEA - STATE INSTITUTE OF THE ENVIRONMENT, 2013. Available at: <www.inea.rj.gov.br>. Accessed on: 10 Oct. 2013.

Krishnamurthy, M.P., Sivapullaiah, P.V., SHAMBAVIKAMATH, 2015. Leachate Characteristics and Evaluating Leachate Contamination Potential of Landfill Sites Using Leachate Pollution Index. The Asian Review of Civil Engineering. v. 4 n. 1, p. 6-13.

Kumar, D., Alappat, B. J., 2003. A technique to quantify landfill leachate pollution. In: Proceedings of the 9th international landfill symposium. Cagliari, Sardinia, Paper n. 400.

Kumar, D., Alappat, B.J., 2005. Evaluating leachate contamination potential of landfill sites using leachate pollution index. Clean Techn Environ Policy. v.7, p. 190-197

Lins, E. A. M., 2011. Study of the characteristics of the leachate from the Muribeca landfill before and after the closure. 26th Brazilian Congress of Sanitary and Environmental Engineering, Porto Alegre, RS. 
Lothe, A.G., Sinha, A., 2016. Development of model for prediction of Leachate Pollution Index (LPI) in absence of leachate parameters. Waste Management.

Mahler, C.F. FUNDAÇÃO COPPETEC/FEDERAL UNIVERSITY OF RIO DE JANEIRO - Project Reports PEC 5556, on the Monitoring of Gases and Laboratory Analyses of Liquid Effluents from Sky Hill Dumpsite. Years: 2004 to 2013. (In Portuguese)

MS - MINISTRY OF HEALTH. Edict 2914 dated December 12, 2001, which contains the procedures for controlling and monitoring the quality of water for human consumption and its standard of potability. Available at: <http://portarquivos.saude.gov.br/images/ pdf/2015/maio/25/Portaria-MS-no-2.914-12-12-2011.pdf>. Accessed on: 28 Oct. 2016

Naveen, B.P., Mahapatra, D.M., Sitharam, T.G., Sivapullaiah, P.V., Ramachandra, T.V., 2016. Physico-chemical and biological characterization of urban municipal landfill leachate. Environmental Pollution. p. 1-12 in press.

Ottoni, V.A., 2011. Simulation of vertical flow in landfill of urban solid waste. Master's Dissertation, Federal University of Rio de Janeiro, COPPE, Civil Engineering Program, 176p.

Pohland, F.G., Harper, S.R., 1985. Critical review and summary of leachate and gas production from landfills. EPA/600/2-86/073. Hazardous Environmental Research Laboratory, Office of Research and Development, United States Environmental Protection Agency. 165 p.

Queiroz, L.M., Amaral, M.S., Morita, D. M., Yabroudi, S.C., Sobrinho, P.A., 2011. Application of physicochemical processes as an alternative of pre- and post-treatment of leachate from landfills. Sanitary and Environmental Engineering. v.16, p. 403-410.
Rafizul, I., Alamgir, M., Islam, M. M., 2011. Evaluation of contamination potential of sanitary landfill lysimeter using leachate pollution index. Sardinia 2011 - Thirteenth International Waste Management and Landfill Symposium, S. Margherita di Pula, Cagliari, Italy.

Reinhart, D.R., Townsend, T.G., 1997. Landfill Bioreactor Design \& Operation. New York - Washington, D.C., CRC Press LLC.

Schueler, A.S., Mahler, C.F., 2008. Evaluation system to classify areas for disposal of urban solid waste for remediation and post-occupation. Sanitary and Environmental Engineering, v. 13, p. 249-254.

Sharma, A., Meesa, S., Pant, S., Alappat, B.J., Kumar, D., 2008. Formulation of a landfill pollution potential index to compare pollution potential of uncontrolled landfills. Waste Management and Research. v. 26 , p. $474-483$.

Souto, G.D.B., Povinelli, J., 2007. Characteristics of landfill leachate in Brazil. 24th Brazilian Congress of Sanitary and Environmental Engineering. Belo Horizonte.

Teixeira, G.P., Ritter, E., Lacerda, G.B.M., Ferreira, J.A., França, R.A. 2007. Considerations on the geotechnical and environmental remediation and monitoring of Salvaterra dump - Juiz de Fora / MG. 24th Brazilian Congress of Sanitary and Environmental Engineering. Belo Horizonte.

Umar, M., Aziz, H.A., Yusoff, M.S., 2010. Variability of Parameters Involved in Leachate Pollution Index and Determination of LPI from Four Landfills in Malaysia. International Journal of Chemical Engineering. p. 6. 